\title{
新羅最初の伽藍興輪寺の諸問題
}

\section{李興 範}

\section{I . 問題の所在}

新羅最初の伽藍である興輪寺は通常，法興王治世 14 年（A. D. 527）に草創され たと傳えられるが, 興輪寺の寺名が史料に初めて現れるのは未雛王治世 3 年（A. D. 264）である. 異次頓の殉敎によって佛㸚が公傳として公認されるまでに複雜な 佛敎傳來と，それに關する樣樣な說があるが，文獻史料及び新羅地域に初期に重 要な 7 伽藍が建てられたという「七處伽藍之墟」に關して詳細に檢討する必要が ある. また現在知られている興輪寺址も發掘調查によって出土した銘文瓦の寺名 から考察されなければならない:よって伽藍の配置形態を含めて，これらの問題 點を論考することが本論の目的である.

\section{II. 未㮲王治世 3 年（A. D. 264）の興輪寺伽藍創建說について}

興輪寺の寺名が史料に初めに見られるのは，私傳として佛敎傳來があった未雛 王治世 2 年の明年 3 年である.『三國遺事』卷 3 , 興法 3 , 阿道基羅（一作我道, 又 阿頭）の條（以後史料(1)と呼ぶ）によると，未雛王治世三年に成國公主が病氣になっ て巫女, 醫院の治療があっても効果がない. その時我道法師が公主を治療して病 氣が治り，王が大いに悅んで，我道法師に所願を下門した。我道法師は「天鏡林 に佛寺を創建して大いに佛法を興隆して, 國のために求福を析願する」と言い, 王が許諾し工事を命令して興輪寺を建立したと記す。上記史料から重要なことは 當時新羅王室と佛教交流があったことを㝝うことができるとともに，新羅に歷史 的に最初の佛寺伽藍が創建され，その寺名を知ることができることである．問題 は佛敎傳來の年である．高句麗が佛敉を公傳として公認した A. D. 372 年よりは るかに早いことから學者たちは史料價値を一貫して無視しているが，それは公傳 と私傳を區別しなかった年代差の誤りから起因したものである. 高句麗も佛䍩が 公認される以前の早い時期に私傳活動としての佛敎傳教活動があったことから， 
新羅も私傳傳來としてそのような傳說があったと思われる. すなわち，保守的な 新羅は「和白會議」による滿場一致制度のため外來の文化を受け入れるのが大變 困難であるから，佛教が公傳として公認されるまで史料等に見えるように複雜多 樣な佛呚傳呚活動があったことを示唆している，要するに，高句麗，百濟，新羅 は國の事情と地理的位置によって佛敎公認の年代差はあるが，佛敎の傳敎活動は 三國がほぼ同時期に行われたことを推論することが可能であろう。當時の興輪寺 伽藍の狀況を史料(1)から見ると, 「... 貧道百無所求．但願創佛寺於天鏡林．大興 佛呚. 奉福邦家爾. 王許之. 命興工. 俗方質儉. 編茅蒀屋. 住而講演. 時或天花 落地. 號興輪寺...」のように, その當時は風俗が素朴, 儉素であることから, 我 道師は天鏡林の神聖な場所で興輪寺を草木を使用して屋根を作って居住しながら 講演したとみられる．すべての學者たちは法興王治世 14 年（A. D. 527）にはじめ て興輪寺が創建されたとする說を支持しているが，上記の史料から判斷すると， 筆者は當時の狀況から考えると阿蘭若處（aranyāyatana）形態の伽藍が造營された と思われる．そのような遺構形態は相當な歲月が經過すると，考古學的に紏明す ることが大變困難なことから考えると，興輪寺の草創年代について深く檢討する 必要があると思われる．また，その當時天鏡林に興輪寺伽藍創建があった可能性 について「七處伽藍之噓」の實體について歷史的な背景から推論してみよう。史 料(1)によると，前佛時代に 7 つの伽藍址があって，後世にその 7 つ伽藍址に新 たに伽藍を建立したことを傳えている．現在，史料に列擧した 7 つの伽藍址は確 認されて遺存している.すなわち, 興輪寺, 永興寺, 皇龍寺, 芬皇寺, 靈妙寺, 四天王寺, 曇嚴寺である. すべて, 新羅時代の初期に建てられた有名な伽藍であ る. 問題は前佛時代に 7 つの伽藍があったかどうかである，筆者はその傳承は信 じ難いが，前佛時代の 7 つの伽藍址は過去七佛を象徵すると同時に, 新羅が佛國 淨土の顯現する國であることを示唆したと思われる，過去七佛は毘婆尸枼佛，尸 棄佛毘舍浮佛, 拘留孫佛, 拘那含牟尼佛, 迦葉佛, 釋迦牟尼佛である. 7 つの伽 藍址を過去七佛の象徵として關聯づける根據は，七處伽藍の一つの皇龍寺址には 迦葉佛が說法したといわれる「宴坐石」が遺存しており，『三國遺事』卷 3 ，塔像 4, 迦葉佛宴坐石の條にも認められるからである. 歷史的な面から考えると筆者 は 7 つ伽藍址は上記の史料(1)に見られる天鏡林, 神遊林等の地名に注目し，そ れを古代三韓時代の「蘇塗」の場所と推測する。蘇塗は神聖な地域である。三韓 時代には政治的支配力が强くなって，從來の祭政一致から祭祀と政治が分離され た．天君といわれる祭祀長は「蘇塗」といわれる別巴を主管し，蘇塗で宗教的な 
祭儀が行われた。儀式の道具と行爲は現在の巫堂（巫琴）の行爲と似通っている. もし，蘇塗の地域に罪人が逃走すれば，誰も捕まえることはできない，秋收感謝 祭として扶餘の迎鼓, 高句麗の東盟, 東濊の舞天, 三韓の十月祭, 春節の新豐祭 等の祭儀が蘇塗で行われたことから, どの程度蘇塗が神聖地域であったかを示唆 している、筆者は我道の母親高道寧が我道に新羅に前佛時代の伽藍址があること を敎え，未來に佛法が興盛するであろうからそこに行って佛法を傳播するよう勸 めた（史料(1)）狀況を考えると，その當時母親高道寧は巫女でなかったかと思われ る、憶測の域を脫しないが，筆者は後に新羅が初期の伽藍を建てる際に，重要な 儀式が行われた蘇塗の神聖な場所で 7 つの伽藍を建立したことと皇龍寺, 四天王 寺等のように護國伽藍が建てられ，鎭護國家の儀式が行われたことは，重要な歷 史的な事實を示唆していると思われる.

\section{III. 法興王治世 14 年（A. D. 527）の興輪寺伽藍創建について}

長い歷史の中で迂餘曲折を經過してようやく佛敎が公認され，共に興輪寺が建 てられ，そして佛敎を公認した法興王自身が王權を辭讓して偩侶になって興輪寺 に居佳したことは (『三國遺事』卷 3, 興法 3, 原宗興法と厭髑滅身條... 以後史料(2) と呼 ぶ), 新羅の歷史の中で最も重要な立場を占めていると思われる. 當時の興輪寺の 伽藍狀況について史料(2)ら窥うと, 法興王治世 14 年（A. D. 527）に佛寺の工事 を始めて, 法興王治世 22 年（A. D. 535）には天鏡林から材木を使用して杜を立 て，階段，基石，佛弇等が形成されて，眞興王治世 5 年（A. D. 544）に完成され たことを窥うことができる．また，史料(2)によると，梁の武帝の初年（A. D. 547） に梁の使臣沈湖が佛舍利を將來し,『三國史記』卷 4, 眞興王治世 10 年 (A. D. 549) の條によれば, 中國の梁が使臣と新羅の留學僧覺德に佛舍利を持ったせて送った ので，王は百官に興輪寺で奉迎することを命じた．上記の兩史料から重要なこと は, 國家の立場から佛敉交流があったことと, 中國から將來した佛舍利を塔に安 置して，新羅に舍利信仰が始まったことを窺うことができる，興輪寺もその當時 佛舍利を塔に安置し, または僧侶が尊敬され, 國家的に重要な位置を占めたと思 われる．紙面の都合で興輪寺伽藍の構造と配置及び銘文瓦「靈廟之寺」寺名の問 題點については別の機会に論ずることにする.

〈キーワード〉 韓國佛敉, 興輪寺, 七處伽藍之墟，蘇塗 